\title{
Development of Learning Devices Based on Problem Based Learning Model to Improve Mathematical Communication Skills
}

\author{
Fitriani Sitopu \\ Mathematics Education \\ Postgraduate Program, Universitas \\ Negeri Medan \\ Medan, Indonesia \\ fitrisitopu@gmail.com
}

\author{
Sahat Saragih \\ Mathematics Education \\ Postgraduate Program, Universitas \\ Negeri Medan \\ Medan, Indonesia
}

\author{
Hasratuddin \\ Mathematics Education \\ Postgraduate Program, Universitas \\ Negeri Medan \\ Medan, Indonesia
}

\begin{abstract}
This study aims to: 1) Find effective tools in mathematics learning that are developed based on the PBM model; 2) Finding an increase in students' mathematical communication skills by using learning tools based on the PBM model; 3) Finding students' responses to learning tools developed based on the PBM model. This research is a development study using the Thiagarajan, Semmel and Semmel (4D) development models. Trials of learning tools based on the PBM model were carried out twice to obtain quality equipment. The first trial (trial I) was conducted in class XI TKJ-1 and the second trial (trial II) was conducted in class XI TKJ-2 SMK Tritech Informatika Medan. The results of the research trials I and trial II obtained: 1) learning devices meet the effectiveness, effective in terms of a) classical student learning completeness; b) achievement of learning objectives; and c) learning time; 2) improvement of students' mathematical communication skills by using learning tools based on PBM models, in the first trial I got an average posttest 73.83 , and increased in the second trial with an average posttest value of $86.67 ; 3$ ) students' responses to the components of the learning tools and learning activities are positive.
\end{abstract}

Keywords: Problem Based Learning Model, mathematical communication skills, development of learning devices, and 4-D models.

\section{INTRODUCTION}

Education is an important field in determining the quality of a nation. Through education, humans will be able to master science and technology, increase human resources, and be able to solve the problems they face. This is in line with Law number 20 of 2003 [1] concerning the national education system that national education functions to develop capabilities and shape the dignified character and civilization of the nation in order to educate the nation's life. Therefore, education must be prepared as a provision of life in the future.

The application of mathematics lessons can make characters in the mindset of students if mathematics is used as a daily language of students. This is in line with the opinion of Hidayati [2] namely "Mathematics is a language, not just a means of mathematical thinking tools, tools to find patterns, but mathematics as well as a vehicle for communication between students and communication between teachers and students. Communication in mathematics and mathematics learning into something are needed. The quote states that mathematics as a language does not only mean mathematics as a means of thinking, but uses mathematics as a means of communication between students and between teacher and students. From the above quotation it appears that the importance of mathematics is used as a means of communication. With mathematical communication skills students will more easily communicate ideas to clarify a problem. Good mathematical communication will affect student mathematics learning, if students have good mathematical communication skills, then students can propose solutions to a mathematical problem in the classroom. With this ability, problems will be more easily solved.

Mathematical communication will provide convenience in improving the quality of student mathematics learning. Low communication skills will result in low student competence. If students have communication skills, it will certainly facilitate students in understanding mathematics deeper and become a capital for the success of learning mathematics. This is in line with Wichelt's statement [3] namely "If students can communicate their steps and answer questions about how they reached the answer, then they have a good understanding of the topic". The meaning of the above statement is that if students are able to communicate the steps and explain how they answer a question, then it can be stated they have a good understanding of a topic or material.

But in reality from the results of the researchers 'initial observations by submitting questions that measure mathematical communication skills on statistical material to Class XI students of SMK Tritech Informatics Medan on May 4, 2017, the results show that students' mathematical communication abilities are still low. This can be seen from the difficulty of students in solving problems that result in low mathematics learning outcomes.

The fact of the low communication skills of students is in line with the results of Perwitasari \& Surya's research [4] at the junior high school level, namely "In reality there have yet faced problems faced by students, especially the lack of 
student's mathematical communication skills". The above quotation implies that in reality, there are no presenting problems to students, especially regarding students' mathematical communication skills. Furthermore, the results of Yusra and Saragih's research [5] on the mathematical communication skills of MTs in Medan stated "The reality found in the field, learning of mathematics for this still little attention to the development of mathematical communication skills, so that the mastery of these competencies for students still low. The above statement means that the reality found in the field, mathematics learning for mathematics communication skills is still lacking in attention, so students' mathematical communication skills are still low.Both of the results of the above study indicate that since in junior high school, students' mathematical communication skills have been weak, so it is not impossible that the weakness carried over to high school or vocational high school.

To be able to develop students' mathematical communication skills needed a learning device that supports. Development of learning tools include learning implementation plans, student books and student activity sheets which must refer to a learning model so that the devices are developed into a single unit that is complementary and focused on the objectives to be achieved. There are many learning models that can be used in an effort develop mathematical communication skills, one of the learning models that is expected to be in line with the characteristics of mathematics is a problem-based learning model.

According to Arends (Trianto) [6] which states that "Problem-based learning is a learning model where students work on authentic problems with a view to compiling their own knowledge, developing inquiry and critical thinking skills, developing independence, and self-confidence". Furthermore Othman, H., Buntat, Sulaiman, Salleh \& Herawan [7] stated "The results from the study show that the potential of PBL to be an alternative method to enhance the employability skills of applied mathematics students". The meaning of this quote is the results of research showing potential problem-based learning as an alternative method to improve students' mathematical abilities.

\section{METHOD}

This type of research is a research development (depelopment research) using the development model of learning tools Thiagarajan, Semmel and Semmel, namely the 4-D model. This research was conducted at Tritech Informatics Vocational School Medan, subjects in this study were all students of class XI Vocational School Tritech Informatics Medan in the odd semester of the 2018/2019 school year, while the object in this study was a learning tool based on a problem-based learning model on statistics material which included: Learning Implementation Plan (RPP), Student Book (BS), Student Activity Sheet (LAS), research instrument that is a test of mathematical communication skills (TKM).

This research was divided into two stages, the first stage was the development of learning tools which included the validity of the lesson plans, student books, LAS, and

mathematical communication skills test instruments. The second stage is testing the learning tools based on the problem based learning model in class XI TKJ-1 and class XI TKJ-2 SMK Tritech Informatika Medan.

Thiagarajan [8] The development of this learning device consists of 4 stages, namely:

1. Defining stage, namely: to determine and define learning needs by analyzing the objectives and boundaries of the material. The activities carried out at this stage are: preliminary analysis, student analysis, concept / material analysis, assignments, and the formulation of learning objectives.

2. Design phase, namely: designing learning tools such as test preparation, media selection, format selection and initial design.

3. The development stage (develop), namely: analyzing, testing, developing, evaluating and revising learning tools.

4. Disseminate stage, namely: Learning tools that have received positive assessments from experts and through development tests are then packaged, distributed and determined for a broader scale.

To measure the validity and effectiveness of learning tools, a research instrument was developed and developed.

The research instrument developed was adjusted to the problem based learning model. These instruments were first validated by experts and tested. Field trials are conducted twice, this is to obtain direct input on the learning tools that have been compiled so as to produce the final set. Development of learning tools reaches the final stage if it has received a positive assessment from experts and through development tests. These learning tools are then packaged, distributed and determined for a broader scale.

The trial design used in this study is a one-shot case study or also called one-group posttest only design. Sumber Arikunto [9] This design is presented as follows:

\section{Treatment $\mathbf{X}$}

Information

$\mathrm{O}$ : Posttest mathematical communication skills $\mathrm{X}$ : Treatment with learning tools based on developed problem-based learning models.

To measure the validity and effectiveness of mathematics learning tools, a research instrument was developed and developed through analysis of the validity and reliability of the data to test (1) the effectiveness of the learning device; (2) improvement of students' mathematical communication; and (3) student responses to the learning process.

\section{RESULT}

Based on the results of the analysis of trial I data, it is known that the learning tools based on the problem-based learning model developed have not met all the effective criteria established. Because, there are still indicators of 
effectiveness that have not been met, namely the results of the posttest mathematical communication skills in trial I by $70 \%$ (not yet fulfilling the classical achievement criteria for completeness), and student responses to the learning device components based on problem-based learning models that were developed positively. The results of trial I that have been carried out are used as a reference for improvements made in trial I, and will be retested in trial II.

Based on the results of the analysis of the trial II data, it is known that the learning tools developed have been effective, such as the results of the posttest mathematical communication skills in the trial II have met the criteria of completeness achievement in a classical manner, the achievement of learning objectives has reached the specified criteria, the achievement of learning time is at least the same with ordinary learning has been achieved.

Descriptions of improving students' mathematical communication skills by using learning tools based on problem based learning models in trials I and II are shown in the following table:

TABLE I. DESCRIPTIONS OF RESULTS OF STUDENTS MATHEMATICAL COMMUNICATION SKILLS

\begin{tabular}{|c|c|c|}
\hline Explanation & Posttest Trial I & Posttest Trial II \\
\hline The highest score & 90 & 97,5 \\
\hline lowest value & 42,5 & 60 \\
\hline Average & 73,83 & 86,67 \\
\hline
\end{tabular}

Furthermore, a description of improving students' mathematical communication skills by using learning tools based on problem-based learning models in trials I and II for each indicator of the ability to understand concepts can be seen in Table II below:

TABLE II. AVERAGE MATHEMATICAL COMMUNICATION SKILLS OF STUDENTSFOR EACH INDICATOR

\begin{tabular}{|c|c|c|c|}
\hline \multirow[b]{2}{*}{ No. } & \multirow{2}{*}{$\begin{array}{c}\text { Indicators of Student } \\
\text { Mathematical Communication } \\
\text { Skills }\end{array}$} & \multicolumn{2}{|c|}{ Average } \\
\hline & & Trial $I$ & Trial II \\
\hline 1 & $\begin{array}{l}\text { State the situation or } \\
\text { mathematical ideas in the form } \\
\text { of images }\end{array}$ & 3,20 & 3,77 \\
\hline 2 & $\begin{array}{l}\text { Connecting real objects or } \\
\text { images into mathematical ideas }\end{array}$ & 3,13 & 3,48 \\
\hline 3 & $\begin{array}{l}\text { Stating questions related to } \\
\text { everyday events into a } \\
\text { mathematical notation or model } \\
\text { and concluding it }\end{array}$ & 2,87 & 3,42 \\
\hline
\end{tabular}

From Table II. above, it appears that the average mathematical communication skills of students in trials I and II. For more details, you can see in Figure I below:

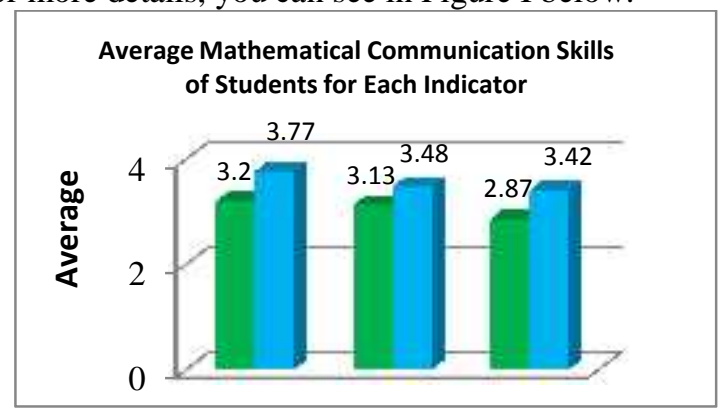

Fig. I. Average Students' Mathematical Communication Skills for Each Indicator
The results of the questionnaire analysis of student responses to the components of learning tools based on problem-based learning models can be said that all aspects of getting a positive response in the first trial the average total percentage of questionnaire responses in the first tryout students was $90.73 \%$, and in the second try is $93.36 \%$, so as such the components of this learning tool are effective for use.

\section{CONCLUSION}

Based on the results of research and discussion, obtained the following conclusions:

1. Learning tools developed based on the PBM model in improving students' mathematical communication skills on statistical material in class XI of SMK Tritech Informatics Medan are effective for use in learning, this is indicated by:

a. The mastery of student learning classically,

b. Achievement of learning objectives,

c. The time spent in applying learning tools based on the PBM model is the same as the normal learning time.

2. Improvement of students 'mathematical communication skills using learning tools based on PBM models in statistical material is the average achievement of students' mathematical communication abilities in the results of the first test posttest of 73.83 increased to 86.67 in the second trial. Thus, an increase in the average value of students' mathematical communication skills by 12.84. In addition, the average of each indicator of students' mathematical communication skills increased from trial I to trial II.

3. Student responses to the components of learning tools based on PBM models and learning activities are positive.

\section{REFERENCES}

[1] Depdiknas. 2003. Sisdiknas No.20 Tahun 2003. Jakarta: Depdiknas.

[2] Hidayati, W., S., 2016. Description Verbal Mathematics Communication of Students Prospective Mathematics Teacher in Teaching Practice, IOSR Journal of Research \& Method in Education (IOSR-JRME, 6(6): 8-11

[3] Wichelt, L., 2009. Communication: A Vital Skill of Mathematics, Action Research Projects. (Online) http://digitalcommons.unl.edu/ mathmidactionresearch/18: 1-32 (diakses 2 Maret 2018)

[4] Perwitasari, D., \& Surya, E., 2017. The Development of Learning Material Using Problem Based Learning to Improve Mathematical Communication Ability of Secondary School Students, International Journal of Sciences: Basic and Applied Research (IJSBAR), 33(3): 200207.

[5] Yusra, D., A., \& Saragih, S., 2016. The Profile of Communication Mathematics and Students' Motivation by Joyful Learning-based Learning Context Malay Culture, British Journal of Education, Society \& Behavioural Science, 15(4): 1-16

[6] Trianto, 2011. Mendesain Model Pembelajaran Inovatif Progesif: Konsep, Landasan dan Implementasinya pada KTSP, Jakarta: Kencana Prenada Media Group

[7] Othman, H., Buntat, Y., Sulaiman, A., Salleh, B., M., dan Herawan, T., 2010. Applied Mathematics cans Enhance Employability Skills Through 
PBL, International Conference on Mathematics Education Research, 8(1): 332-337

[8] Thiagarajan, S., Semmel, D. S. \& Semmel, M. I., 1974. Instructional Development for Training Teachers of Exceptional Children: A sourcebook. Indiana: Indiana University

[9] Arikunto, S. 2009. Prosedur Penelitian, Suatu Pendekatan Praktik. Jakarta: Rineka Cipta 